ISSN: 1410-8917

Jurnal Kimia - Sains \& Aplikasi

e-ISSN: 2597-9914

\section{Jurnal Kimia Sains dan Aplikasi Journal of Scientific and Applied Chemistry}

Journal homepage: http://ejournal.undip.ac.id/index.php/ksa

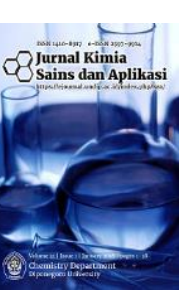

\title{
Cassava Skin Usage (Manihot esculenta L.) as Photocatalyst for Degradation of Methylene Blue in the River of Textile Industrial Zone
}

\author{
Kharisma Madda Ellyana ${ }^{\mathrm{a},{ }^{*}}$, Kharisma Luthfiaratri Rahayu ${ }^{\mathrm{a}}$, Ratri Febriastutia ${ }^{\mathrm{a}}$, Abdul Haris ${ }^{\mathrm{a}}$ \\ ${ }^{a}$ Chemistry Department, Faculty of Sciences and Mathematics, Diponegoro University, Jalan Prof. Soedarto, Tembalang, Semarang \\ * Corresponding author: kharismamadda25@student.undip.ac.id
}

https://doi.org/10.14710/jksa.21.4.232-236

\section{Article Info}

Article history:

Received: 18 August 2018

Revised: 19 October 2018

Accepted: 21 October 2018

Online: 31 October 2018

Keywords:

Cassava Leather; $\mathrm{TiO}_{2} / \mathrm{C}-$

Dot Composite;

Photocatalyst;

Methylene Blue;

Hydrothermal

\begin{abstract}
The progress of the textile industry can increase the amount of dyestuff waste, but often waste disposal is overlooked. The purpose of this research is to provide solution in handling river water pollution by textile industry dye waste. The degradation of textile industry dye waste can be done with $\mathrm{TiO}_{2}$ semiconductors with UV light as a source of irradiation, but only $5 \%$ of sunlight can be utilized $\mathrm{TiO}_{2}$ to excite its electrons, so degradation process is not effective. It needs a material that can optimize the activity of $\mathrm{TiO}_{2}$ semiconductor, one of them $\mathrm{C}$-dot coming from cassava skin. The results obtained in this research were $\mathrm{TiO}_{2} / \mathrm{C}$-dot composite which could degrade methylene blue where its effectiveness was tested using UV-Vis spectrophotometer instrument. $\mathrm{TiO}_{2} / \mathrm{C}$-dot photocatalyst activity test for methylene blue $0.0001 \mathrm{M}$ showed that the concentration of $20 \%$ with the amount of degradation up to $96,99 \%$, best type of rays was sunshine with amount of degradation up to $66,25 \%$ and longest radiation in sunshine with the amount of degradation was up to $78.77 \%$ and UV with the amount of degradation up to $75.99 \%$.
\end{abstract}

\section{Introduction}

Today we know that Indonesia is experiencing rapid progress in the field of industry, one of them in the textile industry. The progress of the textile industry can increase the amount of dyestuff waste, but often waste disposal is overlooked. Disposal of dyestuffs into rivers can result in pollution and harmful to public health. Therefore, appropriate solutions are needed to deal with river water pollution by textile industry dye waste.

The photocatalytic process using $\mathrm{TiO}_{2}$ semiconductors with UV light as a source of irradiation has shown the potential to overcome the problem of dyestuff waste by degrading the dye to a more environmentally friendly compound [1], but only $5 \%$ of sunlight can be utilized $\mathrm{TiO}_{2}$ to excite its electrons due to the large band gap. The basic mechanism for the photocatalyst process is the formation of pairs of electron-holes on the surface of the catalyst when the corresponding photon is energized [2]. The formation of a nanocomposite which is a combination of two distinct components of either one or both scales $\leq 10^{-9} \mathrm{~m}$ or equivalent to the size of the atom or molecule can enhance the photocatalytic activity of $\mathrm{TiO}_{2}$, one of which is the $\mathrm{TiO}_{2} / \mathrm{C}$-dot composite [3]. Research conducted showed that the quantum carbon dot (CQDs) attached to $\mathrm{TiO}_{2}$ surfaces could effectively degrade methyl blue (MB) to close to $100 \%$ [4]. Thus, the $\mathrm{TiO}_{2} / \mathrm{C}$-dot composite is also expected to have such photodegradation capability due to the similarity of the C-dot properties to the CQDs. With this photodegradation method, the dyestuff will be decomposed into components that are simpler and safer for the environment [5].

Only limited as staple food substitutes for rice and raw materials for various processed products, while the skin is often discarded. In fact, cassava skin contains 
starch compounds that can be utilized as carbon sources in the manufacture of carbon nanodot material or better known as C-dot through hydrothermal method [6].

Based on these facts, the innovation to solve the problem of river water pollution by dyestuff waste is the making of cotton-based $\mathrm{TiO}_{2} / \mathrm{C}$-dot nanocomposite (Manihotesculenta L.) as photodegradation material of dyestuff, especially methylene blue compound. The abundance of carbon sources in cassava peel starch compounds is predicted to be engineered into carbon nanodot material which is simply known as $\mathrm{C}-\operatorname{dot}[7]$. The advantages of this innovation are the easy process of making $\mathrm{TiO}_{2} / \mathrm{C}$-dot composites, cheap and abundant raw material sources, and enhanced photodegradation capability against methylene blue compounds.

\section{Materisals and Methods}

\subsection{Materials and Procedures}

Materials used in this study include methylene blue, $\mathrm{TiO}_{2}, \mathrm{NaOH}$, concentrated $\mathrm{HCl}, \mathrm{C}$-dot powder of cassava leather, aquadest, and $96 \%$ ethanol obtained from Merck.

\subsection{Phase of preparation of materials}

The main ingredients in this research, namely cassava leaf waste. Cassava leather as a base material luminescence material has a source of many carbon compounds. The simple synthesis of luminescence material begins with processing the cassava skin into a powder.

\subsection{Phase of C-dot synthesis from Cassava Skin}

The independent variables used in this study are cassava powder of the material preparation stage. Cassava skin was added in $100 \mathrm{ml} 0.1 \mathrm{M} \mathrm{HCl}$ solution and stirred in a magnetic stirer for 1 hour with temperature controlled at $30^{\circ} \mathrm{C}$. Giving the acid aims to break down polymer compounds such as cellulose, and pectin to form a more simple carbohydrate compounds (hydrolysis). The result of the hydrolysis is then neutralized $\mathrm{pH}$ with $100 \mathrm{ml}$ of a strong base of $0.1 \mathrm{M} \mathrm{NaOH}$. At this stage the temperature at the magnetic stirer is raised at $100^{\circ} \mathrm{C}$. The exothermic reaction to the addition of this strong base produces heat so that the carbon chain in the material can break and produce $\mathrm{C}$-dot. Furthermore, characterization of C-dot material with XRD was done.

\subsection{Synthesis $\mathrm{TiO}_{2} / \mathrm{C}$-dot Composite}

The synthesis of $\mathrm{TiO}_{2} / \mathrm{C}$-dot composites was performed by sol-gel method. The $\mathrm{TiO}_{2}$ nanoparticles were prepared by heating the commercial $\mathrm{TiO}_{2}$ at a temperature of $500^{\circ} \mathrm{C}$ for 1 hour. The second stage, $0.1 \mathrm{~g}$ of $\mathrm{TiO}_{2}$ nanoparticles and various $\mathrm{C}$-dot content of cassava leather $(10 \%, 20 \%, 30 \%, 40 \%, 50 \%$ dan $100 \%(\mathrm{w} / \mathrm{w})$ ) added $5 \mathrm{~mL}$ of ion free water with stirring for 10 minute and dried in $80^{\circ} \mathrm{C}$ vacuum oven for 12 hours. After synthesis process is done characterization with XRD and SEM.

\subsection{Photodegradation Activity Test on Methylene Blue}

Photodegradation of the dye was carried out by taking $25 \mathrm{~mL}$ methylene blue $0.0001 \mathrm{M}$ and then added a c-dot photocatalyst of cassava leather, and irradiated by ultraviolet light for $\pm 80 \mathrm{~min}$, after the photocatalysis was finished filtrate was analyzed using visible uv spectrophotometer. Photocatalyst activity test was performed by comparing with standard methylene blue $0.0001 \mathrm{M}$.

\subsection{6. The Effect of Light on Methylene Blue Photodegradation}

Four $50 \mathrm{~mL}$ cups filled with $25 \mathrm{~mL}$ methylene blue 20 $\mathrm{mg} / \mathrm{L}$ solution with different treatment, i.e. first glass containing methylene blue solution; the second glass added $50 \mathrm{mg} \mathrm{C}$-dot. Then photodegradation process is done in photoreactor for 50 minutes using UV light. Furthermore, with the same preparation procedure illuminated by sunlight at 10:00 to 10:50 pm and left in dark conditions. The photodegradation process is done triplo. The methylene blue concentration after the treatment was measured by a UV-Vis spectrophotometer at a wavelength of $664 \mathrm{~nm}$.

\subsection{Influence of Irradiation on Methylene Blue Degradation using $\mathrm{TiO}_{2} / \mathrm{C}$-dot Composite Photocatalyst}

Nine pieces of $50 \mathrm{~mL}$ glass of glass filled $25 \mathrm{~mL}$ of 20 $\mathrm{mg} / \mathrm{L}$ methylene blue solution and $50 \mathrm{mg} \mathrm{C}$-dot was added, then radiation was done by sunlight. Furthermore, with the same preparation procedure illuminated by UV light in the photoreactor. Methylene blue absorbance measurements were performed on the first glass at 5 minute irradiation and measured on the other glass at 10 , $20,30,40,50$, and 60 minutes. The photodegradation process is done triplo. The methylene blue concentration after the treatment was measured by a UV-Vis spectrophotometer at a wavelength of $200 \mathrm{~nm}-800 \mathrm{~nm}$.

\section{Results and Discussion}

\subsection{Synthesis of C-dot from Cassava Skin}

The results obtained from hydrolysis of $\mathrm{HCl}$ neutralized with $\mathrm{NaOH}$ produce heat so that the carbon chain in the material can break and produce $\mathrm{C}$-dot.

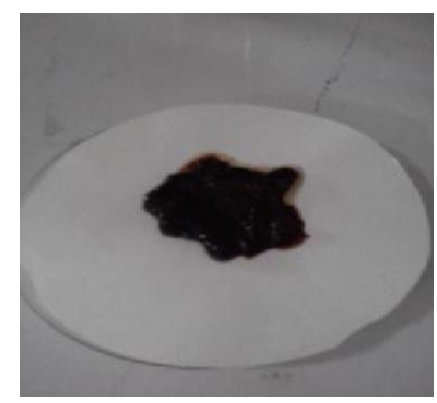

Figure 1: C-dot 


\subsection{Making Composite $\mathrm{TiO}_{2} / \mathrm{C}$-dot}

The result of mixing 0.1 gram of $\mathrm{TiO}_{2}$ nanoparticles and various $\mathrm{C}$-dot grade of cassava leaf $10 \%, 20 \%, 30 \%$, $40 \%, 50 \%$ and $100 \%$ of $\mathrm{TiO}_{2} / \mathrm{C}$-dot composite. This composite has a darker color than $\mathrm{TiO}_{2}$ and is close to a dark brown color.

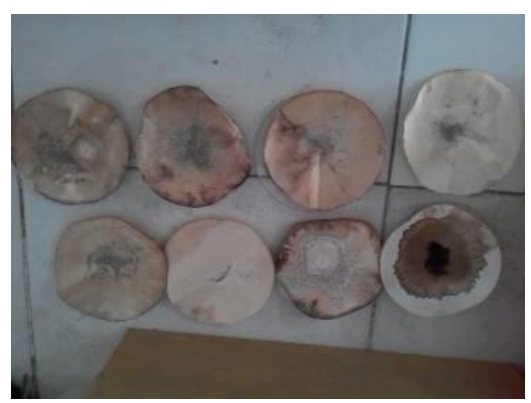

Figure 2: $\mathrm{TiO}_{2} / \mathrm{C}$-dot composite

\subsection{Characterization of $\mathrm{TiO}_{2} / \mathrm{C}$-dot Composite}

The synthesis results were characterized by SEM showing the composite surface morphology of $\mathrm{TiO}_{2} / \mathrm{C}$ dot Nanoparticles with different magnifications.

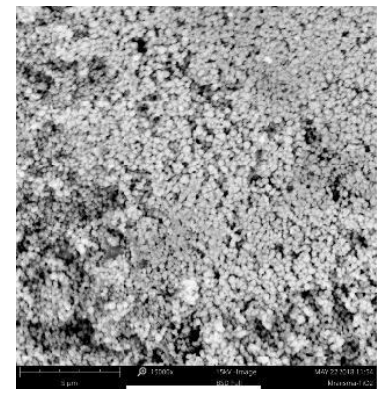

a

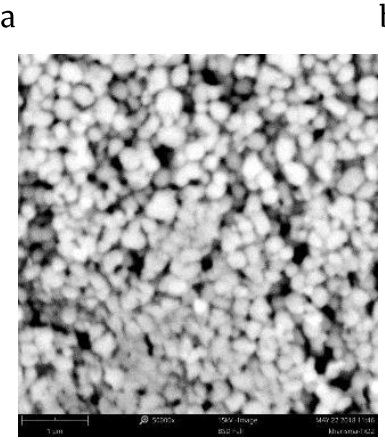

C

Figure 3: (a) SEM Magnification 15000x (b) SEM Magnification 25000x (c) SEM Magnification 50000x

The C-dot influence in the composite can be known from the XRD diffractogram. The intensity and crystallinity of the $\mathrm{TiO}_{2} / \mathrm{C}$-dot composites were less than that of $\mathrm{TiO}_{2}$. This decrease was due to the addition of a relatively amorphous $\mathrm{C}$-dot in the composite. However, there were no significant changes in the XRD pattern of the composites compared to the XRD pattern of $\mathrm{TiO}_{2}$. All peaks on $\mathrm{TiO}_{2} / \mathrm{C}$-dot were similar with the diffraction angle of $\mathrm{TiO}_{2}$, indicating that there was no new compound formed from mixing $\mathrm{C}$-dot with $\mathrm{TiO}_{2}$.

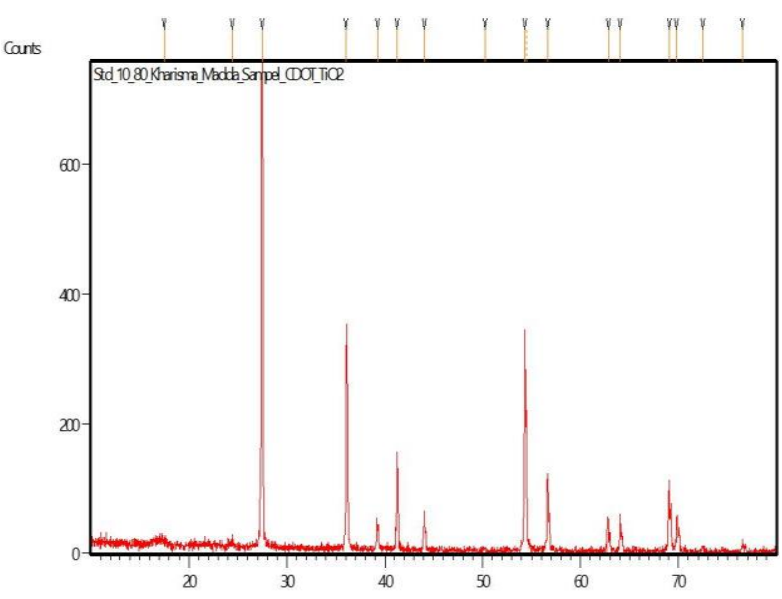

Figure 4: XRD Spectra of $\mathrm{TiO}_{2} / \mathrm{Cdot}$

\subsection{Adsorption Test}

In the analysis that has been done can be known the effectiveness of the use of $\mathrm{TiO}_{2} / \mathrm{C}$-dot in dyestuff degradation Methylen Blue.

\subsubsection{Effect of Concentration on Photodegradation}

The results of the addition of $\mathrm{TiO}_{2} / \mathrm{C}$-dot levels in methylene blue $(25 \mathrm{mg} / \mathrm{L})$ solution processed by the photocatalytic reactor showed color degradation as shown in the following table.

Table 2: Data of analysis of concentration variation on methylen blue degradation

\begin{tabular}{ccccc}
\hline $\begin{array}{c}\text { Concentra- } \\
\text { tion }\end{array}$ & $\begin{array}{c}\text { Absorption } \\
(\%)\end{array}$ & $\begin{array}{c}\text { MB } \\
\text { concentration } \\
\text { remaining }\end{array}$ & $\begin{array}{c}\text { MB } \\
\text { concentration } \\
\text { in } \\
\text { degradation }\end{array}$ & $\begin{array}{c}\text { Effective- } \\
\text { ness }\end{array}$ \\
\hline 10 & 0.858 & 5.546 & 14.454 & 72.268 \\
20 & 0.058 & 0.602 & 19.398 & 96.990 \\
30 & 0.137 & 5.451 & 14.549 & 72.744 \\
40 & 0.286 & 10.056 & 9.944 & 49.722 \\
50 & 0.077 & 3.597 & 16.403 & 82.013 \\
100 & 0.913 & 5.886 & 14.114 & 70.569 \\
\hline
\end{tabular}

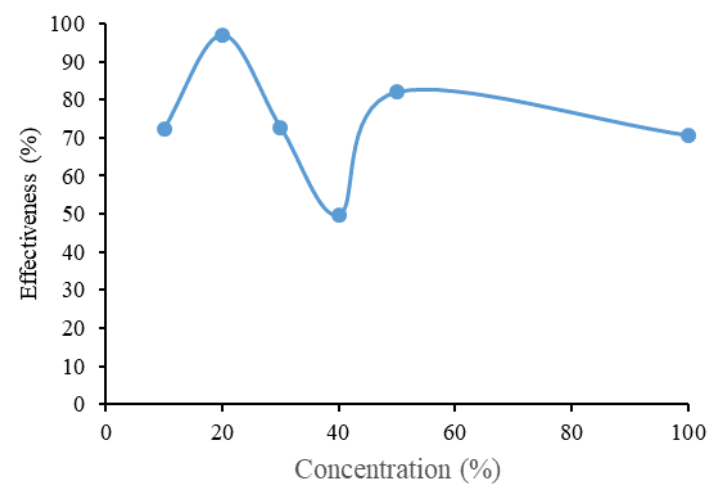

Figure 5: Diagram of the relationship between the concentration of methylen blue degradation

The optimum degradation occurs at $20 \%$. The degradation of each dye is not significant, so it takes longer to reach the desired descent percentage. This is because no catalyst plays a major role in dye reduction. 
The use of UV light without the use of a catalyst can decrease the dye even if the percentage obtained is very small. This is due to the double bond in the reduced dye compound with the help of hv, but the dyestuff compound can not be substantially reduced from the large absorbance value so that the percent value of degradation obtained is very small.

When photocatalysts are exposed to ultraviolet radiation that has the appropriate energy or even exceeds the bandit energy of the oxide titan, the electrons in the valence band of the photocatalyst will be attracted to the conduction band which will produce the ekb and vacancies or holes (hvb) acting as positive charges. Furthermore, hvb will react with the metal hydroxide i.e. the titan hydroxide oxide present in the solution to form a metal hydroxide radical which is a strong oxidizer to oxidize the compounds present in said liquid waste. For electrons present on the semiconductor surface will be trapped in the metal hydroxide and can react with $\mathrm{H}_{2} \mathrm{O}$ or $\mathrm{O} 2$ present in the solution to form hydroxy radical $(-\mathrm{OH})$ or superoxide $(-0)$ which will oxidize the compounds contained in said liquid waste. This radical will be formed continuously as long as $\mathrm{TiO}_{2} / \mathrm{C}$-dot is still exposed to UV radiation and will attack the compound contained in the liquid waste located on the surface of the catalyst so that it will be degraded to produce a harmless compound. So the more photocatalyst is added then the active side that will produce $(-\mathrm{OH})$ more and more [8].

\subsubsection{Effect of Light on Photodegradation}

The results of the analysis of the type of light in the methylene blue solution $(25 \mathrm{mg} / \mathrm{L})$ processed by the photocatalytic reactor show the color degradation as shown in the following table.

Table 3: Data analysis of the type of rays on methylen blue degradation

\begin{tabular}{ccccc}
\hline Variable & $\begin{array}{c}\text { Absorp- } \\
\text { tion }\end{array}$ & $\begin{array}{c}\text { concentra- } \\
\text { tion } \\
\text { remaining }\end{array}$ & $\begin{array}{c}\text { concentration } \\
\text { in } \\
\text { degradation }\end{array}$ & $\begin{array}{c}\text { Effectiveness } \\
(\%)\end{array}$ \\
\hline Sun & 0.179 & 6.749 & 13.251 & 66.255 \\
UV & 0.205 & 7.553 & 12.447 & 62.237 \\
Dark & 0.217 & 7.923 & 12.077 & 60.383 \\
\hline
\end{tabular}

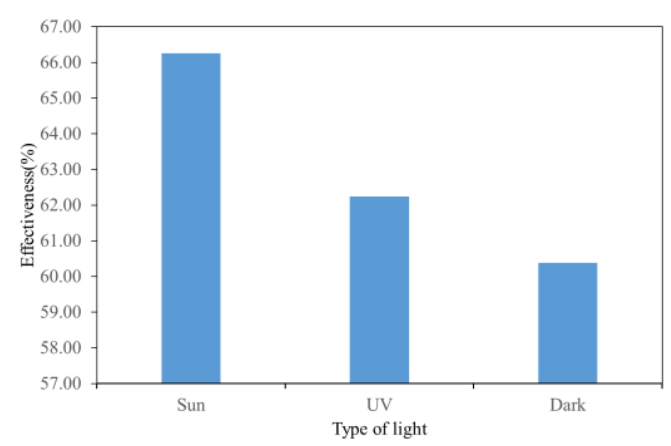

Figure 6: Diagram of the relation between the variation of rays to degradation of methylen blue
The diagram above shows that the degradation value of methylene blue increases in dark conditions, UV rays into sunlight with various photocatalysts. In dark conditions, the degradation value is low because there is no light source so that the photon energy to produce the radical $\cdot \mathrm{OH}$ is weak, therefore methylen blue is only adsorbed on the catalyst surface and its degradation becomes not optimal. This degradation process is due to increasing time which is proportional to increasing UV radiation [9]. In sunlight conditions obtained sunlight results higher than UV light. This is because sunlight has the intensity and wavelength between (310-2300 $\mathrm{nm}$ ) greater than the wavelength of UV light (200-380 nm). In addition, sunlight is a combination of $\pm 45 \%$ visible light and $\pm 5 \%$ of UV light so that sunlight has a relatively large energy and can provide a lot of photon energy on the photocatalyst. Photocatalysts $\mathrm{TiO}_{2} / \mathrm{C}$-dot increase photocatalytic activity up to $\pm 66.25 \%$ UV radiation to sunlight resulting in the most optimum degradation of methylene blue. When the photocatalyst is irradiated with greater energy than the bandgap, a strong oxidizing hole is generated to form an $\mathrm{OH}$ radical and the radical degrades the blue methylene into a simpler compound. From these light effects data, the sun can be used as a potential light source for photocatalysts in degrading methylen blue dyes. Photodegradation of dyes is carried out in the open space (exposed to sunlight). UV light radiation acts as a photon that can produce $\mathrm{OH}$ radicals. which has a large oxidation potential for organic molecules [10].

\subsubsection{The effect of long irradiation on photodegradation}

The time of radiation in the photodegradation process illustrates the length of the interaction (contact) between photocatalyst and light (hv) in generating $\mathrm{OH}$ radicals and contacts between $\mathrm{OH}$ radicals and methylen blue substrates in the degradation process. The results of long and sunlight exposure analysis of methylene shown in the following table.

Table 4: Analyzes of long irradiation data on methylen blue degradation

\begin{tabular}{ccccc}
\hline $\begin{array}{c}\text { Varia- } \\
\text { bles }\end{array}$ & $\begin{array}{c}\text { Absorp- } \\
\text { tion (\%) }\end{array}$ & $\begin{array}{c}\text { MB concen- } \\
\text { tration } \\
\text { remaining }\end{array}$ & $\begin{array}{c}\text { MB concen- } \\
\text { tration in } \\
\text { degradation }\end{array}$ & $\begin{array}{c}\text { Effective } \\
\text { ness (\%) }\end{array}$ \\
\hline M10 & 0.118 & 4.864 & 15.136 & 75.680 \\
M20 & 0.098 & 4.246 & 15.754 & 78.770 \\
M30 & 0.113 & 4.710 & 15.290 & 76.452 \\
M40 & 0.14 & 5.544 & 14.456 & 72.281 \\
M50 & 0.129 & 5.204 & 14.796 & 73.980 \\
M60 & 0.136 & 5.420 & 14.580 & 72.899 \\
UV10 & 0.165 & 6.316 & 13.684 & 68.418 \\
UV20 & 0.224 & 8.140 & 11.860 & 59.302 \\
UV30 & 0.129 & 5.204 & 14.796 & 73.980 \\
UV40 & 0.118 & 4.864 & 15.136 & 75.680 \\
UV50 & 0.116 & 4.802 & 15.198 & 75.989 \\
UV60 & 0.137 & 5.451 & 14.549 & 72.744 \\
\hline
\end{tabular}




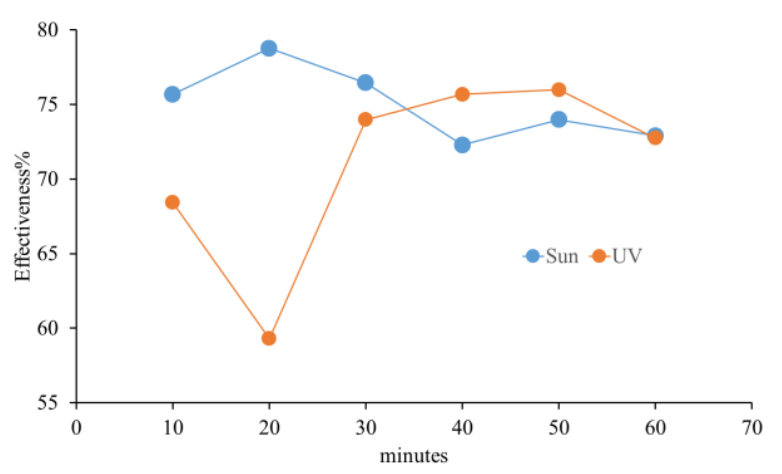

Figure 7: Diagram of the relation between the duration of sun exposure and UV radiation to methylen blue degradation

Diagram shows that degradation of methylen blue optimum at minute 20 with effectiveness equal to $78,77 \%$. This shows that the irradiation time is 20 minutes, the solution dye becomes faded so that methylen blue is easily degraded.

While on UV rays degradation methylen blue optimum at minute 50 with effectiveness equal to $75,99 \%$. This shows that the irradiation time is 50 minutes, the solution dye becomes faded so that methylen blue is easily degraded. Photon energy from sunlight can cause photocatalysts to produce $\mathrm{OH}$ radicals more than photon energy from UV light. Degradation of methylene blue increases with increasing sun exposure in the photodegradation process using $\mathrm{TiO}_{2} / \mathrm{C}$-dot catalyst. The longer the irradiation time, the adsorption and desorption process will run continuously, until it reaches the optimum condition where adsorption and desorption are equilibrium so that degradation tends to be stable close to $100 \%$.

\section{Conclusion}

Based on the result of research, it can be concluded tha photocatalyst of $\mathrm{TiO}_{2} / \mathrm{C}$-dot with concentration variation of $10,20,30,40,50$ and $100 \%$ can be synthesized using hydrothermal method. The results of $\mathrm{TiO}_{2} / \mathrm{C}$-dot photocatalyst characterization using XRD and SEM show that $\mathrm{TiO}_{2}$ has entered the external and internal parts of $\mathrm{TiO}_{2} / \mathrm{C}$-dot. $\mathrm{TiO}_{2} / \mathrm{C}$-dot photocatalyst activity test for blue methylene $0.0001 \mathrm{M}$ showed that the best photocatalyst concentration to degrade methylene blue $0.0001 \mathrm{M}$ at $20 \%$ level with degradation amount up to 96,99\%. $\mathrm{TiO}_{2} / \mathrm{C}$-dot photocatalyst activity test for blue $0.0001 \mathrm{M}$ methylene showed that the best type of rays to degrade methylene blue $0.0001 \mathrm{M}$ is sunlight with the amount of degradation up to $66,25 \%$. $\mathrm{TiO}_{2} / \mathrm{C}$-dot photocatalyst activity test for blue $0.0001 \mathrm{M}$ methylene showed that the best irradiation time to degrade methylene blue $0.0001 \mathrm{M}$ in sunlight with degradation amount up to $78,77 \%$ and UV with amount of degradation up to $75,99 \%$.

\section{Acknowledgment}

We are grateful for the departments of Chemistry, Faculty of Science and Mathematics, University of Diponegoro and PKM (Progam Kreativitas Mahasiswa) KEMENRISTEKDIKTI for research funding. And to thank the Indonesian Ministry of Research, Technology, and Higher Education which sponsored this research.

\section{References}

[1] Renita Manurung, Rosdanelli Hasibuan, Irvan, Perombakan Zat Warna Azo Reaktif Secara Anaerob dan Aerob, in, Fakultas Teknik Universitas Sumatera Utara, Medan, 2004.

[2] Steffita Rahayuning Purbandini, Abdul Haris, Effect of ZnO Dopant on $\mathrm{TiO}_{2}$ on Simultaneous Decrease of Phenol, Pb (II) and COD using Photocatalysis Method, Jurnal Kimia Sains dan Aplikasi, 21, 1, (2018) 34-38 https://doi.org/10.14710/jksa.21.1.34-38

[3] Siti Naimah, Bumiarto Nugroho Jati, Novi Nur Aidha, Agustina Arianita Cahyaningtyas, Degradasi Zat Warna Pada Limbah Cair Industri Tekstil Dengan Metode Fotokatalitik Menggunakan Nanokomposit Tio2-Zeolit, Jurnal Kimia dan Kemasan, 36, 2, (2014) 225-236 http://dx.doi.org/10.24817/jkk.v36i2.1889

[4] Hengchao Zhang, Hui Huang, Hai Ming, Haitao Li, Lili Zhang, Yang Liu, Zhenhui Kang, Carbon quantum dots/Ag3PO4 complex photocatalysts with enhanced photocatalytic activity and stability under visible light, Journal of Materials Chemistry, 22, 21, (2012) 10501-10506 http://dx.doi.org/10.1039/C2JM30703K

[5] S. Corrent, G. Cosa, J. C. Scaiano, Maria S. Galletero, Mercedes Alvaro, H. Garcia, Intrazeolite Photochemistry. 26. Photophysical Properties of Nanosized TiO2 Clusters Included in Zeolites $Y, \beta$, and Mordenite, Chemistry of Materials, 13, 3, (2001) 715722 http://dx.doi.org/10.1021/cm990679+

[6] Sheau-Ming Chen, Ming-Shien Yen, Yun-Hwei Shen, Effect of chitosan biopolymer and UV/TiO 2 method for the de-coloration of acid blue 40 simulated textile wastewater, African Journal of Biotechnology, 9, 34, (2010) 5575-5580

[7] Y. Sudaryanto, S. B. Hartono, W. Irawaty, H. Hindarso, S. Ismadji, High surface area activated carbon prepared from cassava peel by chemical activation, Bioresource Technology, 97, 5, (2006) 734-739 https://doi.org/10.1016/j.biortech.2005.04.029

[8] Andy Alfan Qodri, Fotodegradasi Zat Warna Remazol Yellow FG dengan Fotokatalis Komposit $\mathrm{TiO}_{2} / \mathrm{SiO}_{2}$, Jurusan Kimia, Universitas Sebelas Maret, Surakarta

[9] Sofian Ansori, Sriatun Sriatun, Pardoyo Pardoyo, Modifikasi Zeolit Alam Menggunakan $\mathrm{TiO}_{2}$ sebagai Fotokatalis Zat Pewarna Indigo Carmine, Jurnal Kimia Sains dan Aplikasi, 19, 2, (2016) 68-71 https://doi.org/10.14710/jksa.19.2.68-71

[10] Maranti Sianita Sianita, Adi Darmawan, Choiril Azmiyawati, Uji Aktivitas Fotokatalis Genteng Berglasir Silika/TiO2 terhadap Degradasi Larutan Indigo Carmine, Metanil Yellow dan Rhodamin, Jurnal Kimia Sains dan Aplikasi, 20, 2, (2017) 53-57 https://doi.org/10.14710/jksa.20.2.53-57 